\title{
'n Profiel van verpleegadministrateurs in privaathospitale
}

\author{
Marie E Muller, MC van Huyssteen, Anne-Marie Bruwer
}

\section{INLEIDING}

Die rol van die verpleegadministrateur het die afgelope dekade 'n klemverskuiwing ondergaan. Faktore wat hierdie klemverskuiwing in haar/sy rol beinvloed, sluit onder meer die groter spesialisering van gesondheidsienste en bestuurstelsels; die privatisering en politisering van gesondheidsdienste, verwagtinge van die pasient, veranderde personeelsamestelling en mobiliteit, asook ekonomiese knelpunte in.

'n Kritiese ontleding van die rol en verantwoordelikhede van die verpleegadministrateur in stedelike provinsiale hospitale is deur Robertson (1984) gemaak vanuit 'n perspektief op die verlede, hede en toekoms. Sy bevind onder meer dat hierdie rol baie kompleks geraak het en dat die verpleegadministrateur dit moeilik vind om by die rolveranderinge en die eise wat vandag aan haar/hom gestel word, aan te pas.

Die verpleegadministrateur is aanspreeklik vir die gehalte van verpleging wat in haar/sy diens gelewer word. Aanspreeklikheid het volgens Bergman (1982: 8-9) sekere voorvereistes, te wete vermoens, verantwoordelikheid en gesag. Vermoß̌ns sluit ook kennis, vaardighede en waardes in. Dit impliseer dat die verpleegadministrateurs in privaathospitale ook oor sekere vermoëns (kennis, vaardighede en waardes) moet beskik ten einde hul bestuursrol toereikend te kan vervul.

Die privatisering van gesondheidsdienste is, met die uitreiking van die Witskrif oor Privatisering en Deregulering in die Republiek van Suid-Afrika (Suid-Afrika, 1987), deur die regering as beleid aanvaar. Met die uitbreiding van gesondheidsdienslewering deur die privaatsektor in Suid-Afrika word die daarstelling van gehalteversekeringsmeganismes 'n noodsaaklikheid (Snyckers, 1986: 22-25). Verskeie meganismes word tans ondersoek ten einde die gehalte van dienslewering en die toepassing van standaarde in privaathospitale te verseker (Suit-Afrika, 1988: 14). Die formalisering van gehalteversekering in privanthospitale stel dus verdere eise aan die verpleegadministrateurs.

Aangesien daar geen inligting betreffende die profiel van verpleegadministrateurs in privaathospitale beskikbaar is nie, ontstaan die

\section{UITTREKSEL}

Die doel van hierdie studie was on geselekcerde demografiese, biografies, op. voedkundige en professionele agtergrondeienskappe van die verpleegadministrateur in Suid-Afrikaanse privachospitale te identifiseer, beskryf en 'n profiel van hierdie eienskappe op te stel. Die resuliate toon dat die verpleegadministrateur in Suid-Afrikaanse privaathospitale nie toereikend vir haar/sy bestuursver-antwoordelikhede voorberei is nie maar oor genoegsame kliniese kennis (volgens die geregistreerde kliniese kwalifikasies) beskik om die nodige gehaltebeheer en-versekering in die verskeie verpleegdissiplines uit te oefen.

\section{ABSTRACT}

The purpose of this study was to identify and describe selected demographical, biographical, educational and professional background characteristics of the nurse administrator in private hospitals and to construct a profile of these char. acteristics. The results show that the nurse administrator in South African private hospitals is not adequately prepared for her/his managerial responsibilities. She is, however, according to the registered clinical qualifica. tions, adequately qualified to exercise quality control and assurance in the various nursing disciplines.

vraag of hierdie groep verpleegadministrateurs cor die nodige ervaring en kennis beskik om aan hierdie eise en rolverwagtinge te voldoen.

Die doel van hierdie ondersoek was soos volg:

- die identifisering en beskrywing van geselekteerde demografiese, biografiese, opvoedkundige en professionele agtergrondeienskappe van die verpleegadministrateur in Suid-Afrikaanse privaathospitale; en

- om 'n profiel van hierdie eienskappe op te stel.

\section{DEFINIËRING VAN TERME}

Profiel

'n Profiel venwys na die toepaslike persoonlike, opvoedkundige, indiensnemings- en professionele inligting van verpleegadministrateurs in Suid-Afrikaanse privaathospitale.

Verpleegadministrateur

Die verpleegadministrateur is 'n geregistreerde verpleegkundige wat in beheer van 'n verpleegdiens in 'n privaathospitaal is. 'n Verpleegadministrateur, matrone en verpleegdiensbestuurder, word as sinonieme in hierdie ondersoek gebruik.

\section{Privanthospitaal}

'n Privaathospitaal is 'n gesondheidsdiensinstelling wat deur 'n private instansie met 'n winsmotief bedryf word.

\section{NAVORSINGSMETODE}

'n Profiel van die verpleegadministrateurs in Suid-Afrikaanse privaathospitale is by wyse van 'n verkennende beskrywende opname bepaal.

Die teikenpopulasie vir hierdie navorsingsdoelstelling sluit alle verpleegadministrateurs in privaathospitale (met ' $n$ winsmotief) in Suid-Afrika in. 'n Lys van die teikenpopulasie is gekonstrueer deur middel van die hospitaaljaarboek (Hospital and Nursing Year Book of Southern Africa, 1988), asook inligting verkry vanaf die Departement van Gesondheidsdienste en Welsyn, Administrasie: Volksraad.

Transvaal beskik oor die meeste privaathospitale, te wete ses-en-veertig, waarvan twaalf in die kategoriez 100-199 en 200 of meer beddens ressorteer (vergelyk Tabel 1).

\section{Tabel 1}

Provinsiale verspreiding van privaat hospitale in Suid-Afrika volgens grootte en beddetal

\begin{tabular}{|c|c|c|c|c|c|}
\hline Proviasie & \multicolumn{5}{|c|}{ Aantal beddens } \\
\hline \multirow{6}{*}{ 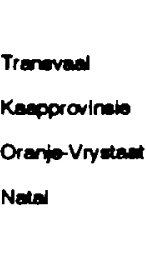 } & $1-40$ & $50-80$ & $100-18$ & $200+$ & Toter \\
\hline & $\theta$ & 13 & 12 & 12 & 48 \\
\hline & 11 & t & 4 & 5 & 28 \\
\hline & 0 & 0 & 2 & 0 & 2 \\
\hline & 4 & 0 & 2 & 2 & 8 \\
\hline & 24 & 21 & 20 & 19 & 84 \\
\hline
\end{tabular}


Dic Kaapprovinsie beskik oor 'n total van agt-en-twintig privaathospitale waarvan nege oor 100 of meer beddens, beskik. Natal het slegs agt privaathospitale waarvan vier 100 of meer beddens het en die Oranje-Vrystaat beskik oor slegs twee privaathospitale. Die teikenpopulasie bestaan dus uit vier en tagtig privaathospitale met die verpleegadministrateurs as spesifieke ontledingseenheid.

Die totale teikenpopulasie, naamlik vier-entagtig hospitale, is doelbewus vir hierdie studie as steckproefpopulasie geneem en sluit dus alle verpleegadministrateurs in privaathospitale as ontledingseenheid in.

Omdat die steekproefpersone Wyd verspreid oor Suid-Afrika is en die vrae hoofsaaklik demo-biografies van aard is, is 'n gestruktureerde posvraclys as navorsingsinstrument gekies.

Die vraelys bestaan uit agt bladsye en bevat hoofsaaklik gestruktureerde, geslote vrae. Die opname is in vier afdelings verdeel en vrae is daarvolgens deur die navorser ontwerp. Afdeling A handel oor persoonlike data, afdeling B oor opvoedkundige inligting, afdeling $\mathrm{C}$ oor indiensnemingsinligting en in afdeling $D$ is tersaaklike professionele inligting ingewin.

Die inhoudseleksie van vrae is gegrond op soortgelyke opnames deur die Suid-Afrikaanse Verplecgstersvereniging (1985), wat gedurende 'n sensusopname in 1985 biodemograficse inligting ingewin het; Robertson (1984) se ondersoek na die

verpleegadministrateur in Suid-Afrika (stedelike provinsiale hospitale) en Brink (1984) wat 'n profiel van die verpleegdosent in SuidAfrika opgestel het.

Die inligting in afdeling $D$ van die vraelys is gebaseer op 'n literatuurstudie betreffende die bestuursfunksie van die verpleegadministrateur, ten einde die verpleegadministrateur se opvoedkundige behoeftes met betrekking tot verpleegdiensbestuur te bepaal.

Sig- en inhoudsgeldigheid betreffende die biografiese data is deur 'n navorsingskonsultant, en betreffende die professionele data deur drie senior verpleegadministrateurs wat by die voortoetsing betrokke was, bevestig. Aangesien geen meting in hierdie studie tersaaklik is nie, is geen statistiese betroubaarheid van die instrument verreken nie.

'n Loodsstudie is uitgevoer ten einde enige verwarrende terminologie, bewoording of instruksies te elimineer, om responsopsies van die vrae te verhoog en om die siggeldigheid van die instrument te bepaal.

Die vraelyste is in albei landstale aan die steekproefpersone gepos. Skriftelike versoek tot deelname aan die studie is met versending van die vraelyste aan die steekproefpersone gerig. Geen persoon is onder verpligting geplaas om die vraelys te volooi nie - deelname was vrywillig en anoniem. 'n Totaal van vieren-tagtig vraelyste is versend.
Die data is deur middel van 'n rekenaar, met behulp van die SPSS-X pakket (Statistical Package for the Social Sciences) verwerk. Kruistabelle is gebruik om verskille tussen veranderlikes aan te dui en Chi-kwadraattoetsing is, waar van toepassing, uitgevoer om die betekenisvolheid van verskille tussen veranderlikes (provinsiale groepe) aan te dui. Geen statisties betekenisvolle verskille is verkry nie.

\section{RESULTATE}

\section{Realisasie}

'n Totaal van agt-en-sestig uit 'n potensiaal van vier-en-tagtig vraelyste is terugontvang wat ' $n$ besonder hoe realisasiesyfer van $81 \%$ verteenwoordig. Albei die vraelyste wat aan die privaathospitale in die Oranje-Vrystaat gepos is, asook die agt vraelyste wat aan $\mathrm{Na}$ talse privaathospitale gepos is, is terugontvang. In Transvaal het een-en-veertig uit die ses-en-veertig (89\%) verplcegadministrateurs hul vraelyste betyds teruggestuur. Die kaapprovinsie het die swakste gereageer, te wete sewentien uit die agt-en-twintig (61\%) wat egter steeds 'n goeie respons verteenwoordig.

\section{Persoonlike inligting}

In hierdie afdeling is demografiese en biografiese inligting versamel en sluit geslag, huwelikstatus, ouderdom, bevolkingsgroep, getal afhanklikes en huistaal in.

\section{a) Geslag}

Die verpleegadministrateurs in Suid-Afrikaanse privaathospitale is tans hoofsaakjik vroulik. Slegs twee (3\%) van die agt-en-sestig respondente is manlik.

\section{b) Huwelikstatus}

Sewentien (25\%) van die respondente is nooit getroud nie terwyl die meeste respondente, te wete agt-en-dertig (56\%), ten tye van die ondersoek getroud was. Sewe (10\%) en ses $(9 \%)$ respondente was geskei of 'n weduwee onderskeidelik, wat 'n totaal van $19 \%$ weerspieel.

'n Analise van hierdie gegewens bepaal dat die respondente benewens die rol van verpleegadministrateur, ook 'n gesinsrol vervul, aangesien meer as die helfte (56\%) van die respondente ten tye van die studie getroud was.

\section{c) Ouderdomsgroep}

Die meeste respondente, naamlik nege-entwintig (43\%), was in die ouderdomsgroep 35 44 jaar terwyl twintig (29\%) respondente in die ouderdomsgroep van 45-54 jaar geressorteer het. Die jonger en ouer oderdomsgroepe, naamlik 25-34 jaar, asook 55 jaar en ouer, is deur nege (13\%) en tien (15\%) respondente onderskeidelik verteenwoordig. 'n Ontleding van die kruistabelgegewens toon dat die twee nasionale verpleegadministrateurs onderskeidelik in die ouderdomsgroepe 35-44 en 45-54 jaar geressorteer het.
Hierdie resultate verskil van Robertson (1984: 244-245) se bevindinge betreffende die ouderdom van die verpleegadministrateur in stedelike provinsiale hospitale waar $35,8 \%$ in die ouderdomsgroep 40-49 jaar en $49 \%$ in die kategorie 50-59 jaar geressorteer het. Die gemiddelde ouderdom van die verpleegadministrateur in provinsiale hospitale was in 1984 vyftig jaar teenoor die verpleegadministrateur in privaathospitale se gemiddelde ouderdom van twee-en-veertig jaar in 1989.

Studies deur Goodrich (1982: 43) en Whetsone (1977: 55) het getoon dat die gemiddelde ouderdom van verpleegadministrateurs in die Verenigde State van Amerika tussen veertig en nege-en-veertig jaar gewissel het. Hierdie bevindinge stem grootliks ooreen met die bevindinge van hierdie studie.

Wannecr die respondente se ouderdom volgens provinsies ontleed word is dit opmerklik dat die jonger respondente, in die ouderdomsgroep 25-34 jaar, slegs in die Kaapprovinsie en Transvaal werksaam was. Die ouderdomsverspreiding in die ander ouderdomsgroepe toon provinsiaal 'n proporsionele verspreiding en geen statisties betekenisvolle verskil is deur 'n Chi-kwadraattoets bevestig nie ( $p$ > 0,81).

\section{d) Bevolkingsgroep}

Die verpleegadministrateurs in privaathospitale was hoof-saaklik vanuit die blanke bevolkingsgroep wat vyf-en-sestig (96\%) verteenwoordig het, teenoor die Asiatiese en kleur-lingbevolkingsgrope met elk een (1\%) en twee (3\%) respondente onderskeidelik.

\section{e) Afranklikes}

Die meeste respondente het afhanklikes wat hul gesinsrol bevestig. 'n Total van negentien $(28 \%)$ respondente het twee tot vier afhanklikes terwyl sestien (23\%) respondente die verantwoordelikheid van slegs een afhanklike het. In die geval van twee (3\%) respondente is daar meer as vier afhanklikes na wie hul, benewens hul bestuursverantwoordelikhede, cok moet omsien.

'n Vergelyking van hierdie gegewens met Robertson (1984: 246-247) se bevindinge in stedelike provinsiale hospitale, toon 'n relatiewe coreenkoms in die kategorie "geen afhanklikes" waar 50,9\% in hierdie kategorie geressorteer het. Dit is egter opmerklik dat $28 \%$ van die respondente in die privaathospitale twee of meer afhanklikes het teenoor die bykans $45 \%$ in provinsiale hospitale, ten spyte van die groot verskil in getroude status tussen die twee studiegroepe. Hierdie resultate mag verklaar word vanuit die groter getal weduwees/geskeides wat in die openbare sektor die geval was, naamlik $34 \%$ teenoor $19 \%$ in die privaatsektor.

\section{f) Huistaal}

'n Redelik gelyke verspreiding van Afrikgans teenoor Engels as huistaal is gevind. Die helf- 
te van die respondente is Engels-sprekend teenoor twee-en-dertig (47\%) wat Afrikaans as hul huistaal aangegee het. Een blanke respondent het Duits as huistaal aangedui terwyl een kleurlingrespondent aangetoon het dat sy 'n "ander" taal spreek.

\section{Opvoedkundige inligting}

Inligting betreffende basiese verpleegopleidingsprogram, professionele en ander kwalifikasies, asook deelname aan formele studie, is in hierdie afdeling ingewin.

\section{a) Basiese verpleegopleidingsprogram}

Die meeste respondente, te wete agt-en-vyftig $(85 \%)$, het hul basiese verpleegopleiding op diplomavlak (Suid-Afrikaanse Raad op Verpleging) voltooi. Slegs drie (4\%) respondente het 'n baccalaureusgraad gevolg en ses (9\%) respondente het ' $n$ "ander" basiese verpleegopleidingsprogram, hoofsaaklik buitelands, gevolg. Hierdie ander verpleegopleidingsprogramme sluit een Rhodesiese, een Hollandse en een Skotse program in en drie respondente het aangedui dat hulle Engeland se program gevolg het.

Hierdie resultate verskil van Roberison (1984: 252) se studie wat getoon het dat $10 \%$ van die verpleegadministrateurs vanuit die nie-akademiese provinsiale hospitale ' $n$ basiese graadopleiding deurloop het.

\section{b) Professionele kwalifikasies}

Al die respondente beskik oor Algemene Verpleegkunde en sestig (88\%) respondente oor Verloskundige Verpleegkunde as basiese kwalifikasies (vergelyk figuur 1). Hierdie resultate vergelyk gunstig met die nasionale profiel van die verpleegmag waar $83 \%$ van die verpleegkundiges ook as Vroedvroue geregistreer is (Suid-Afrikaanse Raad op Verpleging, 1988). 'n Ontleding van die kruistabelgegewens toon dat die agt respondente wat nie oor Verloskunde as basiese kwalifikasie beskik nie, afkomstig is vanuit die Kaapprovinsie (twee), Natal (twee) en Transvaal (vier). Aangesien Natal deur slegs agt respondente in hierdie studie verteenwoordig was, is $25 \%$ van hierdie verpleegadministrateurs nie as vroedvroue geregistreer nie. Daar moet egter in gedagte gehou word dat Natal vier privaathospitale het (vergelyk tabel 1) wat in die kategorie 1-49 beddens ressorteer. ' $n$ Verdere ontleding toon dat die agt respondente, wat aangetoon het dat hulle nie as vroedvroue geregistreer is nie, wel verloskundige verpleging as 'n verpleegdissipline in hul onderskeie hospitale aangedui het.

Wanneer die resultate oor die aard van verpleging (dissiplines) in die onderskeie hospitale/klinieke ontleed word (vergelyk figuur 5), waar een-en-dertig ( $46 \%$ ) respondente aangedui het dat verloskundige verpleging in hul hospitaal beoefen word, is die getal respondente wat oor 'n verloskun-dige kwalifikasie beskik, teleurstellend laag.
Slegs twintig (29\%) respondente beskik oor Verpleegadministrasie as 'n addisionele kwalifikasie terwyl Operasiesaalverpleegkunde die volgende hoogste frekwensie registrasies toon, naamlik sewentien (25\%) respondente. Gemeenskapsverpleegkunde volg met vyftien (22\%) respondente en Ver-pleegonderwys met elf $(16 \%)$ respondente. Nege $(13 \%)$ respondente beskik oor Psigiatriese Verpleegkunde terwyl ses $(9 \%)$ respondente Intensiewe Verpleegkunde as addisionele kwalifikasies geregistreer het. Drie (4\%) respondente het Pediatriese Verpleegkunde (twee uit Transvaal en een uit die Kaapprovinsie), twee (3\%) Ortopediese Verpleegkunde (albei uit Transvaal), en een (2\%) Onkologiese Verpleegkunde (uit Transval) as addisionele kwalifikasies by die Suid-Afrikaanse Raad op Verpleging geregistreer (vergelyk figuur 1).

Robertson (1984: 250-253) se bevindinge in stedelike provinsiale hospitale toon dat $91 \%$ van die verpleegadministrateurs oor die kwalifikasie verpleegadministrasie beskik. Die resultate in hierdie studie, te wete $29 \%$, vergelyk dus swak met die verpleegadministrateur se eweknie in die openbare sektor.

Dit is opmerklik dat nie een van die twee verpleegadministrateurs in die Vrystaatse privaathospitale oor die kwalifikasie verpleegadministrasie beskik nie. In die Kaapprovinsie het vier uit die sewentien (24\%) verpleegadministrateurs 'n kwalifikasie in verpleegadministrasie, terwyl die helfte van Natal se agt verpleegadministrateurs oor dié kwalifikasie beskik. Van die een-en-veertig verpleegadministrateurs wat Transvaalse privaathospitale verteenwoordig het, beskik twaalf (29\%) oor hierdie kwalifikasie.

In die openbare sektor vereis die Personeeladministrasiestandaard (Kommissie vir Administrasie, 1986) dat ' $n$ verpleegkundige, wat vanaf die pos Hoofverpleegkundige na dié van Verpleegdiensbestuurder bevorder word, or verpleegadministrasie as addisionele kwalifikasie beskik. Aangesien minder as 'n derde van die verpleegadministrateurs in privaathospitale oor hierdie kwalifikasie beskik, blyk dit dat hierdie standaard nie in die privaatsektor as essensicel gereken word nie.

'n Relatief groot aantal verpleegadministrateurs in privaathospitale, naamlik $13 \%$, beskik or Psigiatriese Verpleegkunde teenoor 3,8\% in stedelike provinsiale hospitale (Robertson, 1984: 251). Hierdie resultate vergelyk ook gunstig met die nasionale profiel van die verpleegmag waar bykans $11 \%$ van alle verpleegkundiges in Psigiatriese Verpleegkunde geregistreer is (Suid-Afrikanse Raad op Verpleging, 1988). Dit is egler opmerklik dat geen verpleegadministrateur in Natalse privaathospitale oor hierdie kwalifikasie beskik nie terwyl twee uit die Kaapprovinsie, een uit die Oranje-Vrystaat en ses vanuit Transvaal, in Psigiatriese Verpleegkunde geregistreer is.
In stedelike provinsiale hospitale beskik 55\% verpleegadministrateurs oor Gemeenskapsverpleegkunde (Robertson, 1984: 251) teenoor $22 \%$ in die privaathospitale. Hierdie resultate vergelyk egter gunstig met die nasionale verpleegmagprofiel waar Gemeenskapsverpleegkunde deur ongeveer $10 \%$ verpleegkundiges geregistreer is (Suid-Afrikaanse Raad op Verpleging, 1988: 58). Hierdie resultate vergelyk egter swakker met die Suid-Afrikaanse Verpleegstersvereniging (1989: 15) se kaleidoskoopsensusresul tate wat aangetoon het dat $25 \%$ geregistreerde verpleegkundiges $\infty 0 r \mathrm{Ge}$ meenskapsverpleegkunde as addisionele kwalifikasie beskik. Die provinsiale verspreiding van hierdie kwalifikasie toon ook 'n redelike variasie in hierdie studie. In Transvaal beskik elf uit die een-en-veertig (27\%) respondente oor Gemeenskapsverpleegkunde teenoor een uit die twee in die Oranje-Vrystaat, een uit die agt (13\%) in Natal en twee uit die sewentien (12\%) verpleegadministrateurs in die Kaapprovinsie.

Die strewe na die lewering van 'n omvattende gesondheidsdiens in Suid-Afrika vereis dat die verpleegadministrateur oor hierdie gespesialiseerde kennis moet beskik. Human (1987: 175) bevestig dat gemeenskapsverpleging nie, soos dikwels aanvaar word, hoofsaaklik buite hospitaalverband beofen word nie, aangesien die hospitaal met sy personeel, pasiente, besoekers en omgewing, per definisie juis 'n eiesoortige gemeenskap is. Human (1987: 177) huldig ook die mening dat 'n bedryfsgesondheidsdiens vir hospitaal personeel 'n noodsaaklikheid in 'n hospitaal is. Dit is daarom belangrik dat die verpleegadministrateur in hospitale oor epidemiologiese navorsingsvaardighede moet beskik.

Dit is interessant om daarop te let dat $25 \%$ van die verpleegadministrateurs in privaathospitale oor die kwalifikasie Operasiesaalverpleegkunde beskik teenoor $15 \%$ in stedelike provinsiale hospitale (Robertson, 1984: 252). Hierdie resultate is ook aansienlik hoer as die nasionale verpleegmagprofièl van $4 \%$ (SuidAfrikaanse Raad op Verpleging, 1988: 56) en $13,4 \%$ (Suid-Afrikaanse Verpleegstersvereniging, 1989: 15).

'n Verdere ontleding van die gegewens in die kruistabelle toon dat die verpleegadministrateur in Transvaalse privaathospitale 'n hour persentasie operasiesaalverpleegkunde registrasies het, te wete twaalf uit die een-en-veertig (29\%), teenoor die Kaapprovinsie waar vier uit die sewentien ( $24 \%$ ) verpleegadministrateurs oor hiendie kwalifikasie beskik. Intensiewe Verpleegkunde daarteenoor het weer 'n hokr persentasie registrasies in die Kaapprovinsie waar vyf uit die sewentien (29\%) verpleegadministrateurs oor hierdie kwalifikasie beskik teenoor slegs een uit die een-en-veertig verpleegadministrateurs in Transvaalse privaathospitale.

Die verpleegadministrateur in privaathospitale blyk klinies toereikend gekwalifiseerd te 
wees. Die 9\% registrasies in Intensiewe Verpleegkunde is aansienlik hoer as die nasionale verpleegmagprofiel van $2,8 \%$. Ortopediese Verpleegkunde (3\%) en Pediatricse Verplecg kunde (4\%) vergelyk ook gunstig met die nasionale verpleegmagprofiel van $1,2 \%$ en $2,3 \%$ onderskeidelik (Suid-Afrikaanse Raad op Verpleging, 1988: 56-57).

'n Analise van die gegewens in die afdeling van die vraelys wat oor die aard van verpleging in die hospitaal (kliniek) handel, dui op 'n wye verskeidenheid kliniese spesialiteitsareas in verpleging in die privaathospitale. Uit die voorafgaande resultate blyk dit dat die verpleegadministrateur in privaathospitale klinies toereikend voorberei is vir gehaltebeheer en versekering in hierdie dissiplines.

Verdere professionele kwalifisering as dosent blyk nie vir die verpleegadministrateurs in privaathospitale 'n prioriteit te wees nie. Alhoewel $16 \%$ hoer as die nasional verkpleegmagprofiel van 3,6\% is (Suid-Afrikaanse Raad op Verpleging, 1988: 57-58), vergelyk dit swak met die verpleegadministrateur in stedelike provinsiale hospitale waarvan bykans $55 \%$ oor hierdie addisionele kwalifikasie beskik (Robertson, 1984: 251).

'n Ontleding van die knistabelgegewens toon dat beide die nasionale verpleegadministrateurs in hierdie studie oor registrasies in verloskundige, gemeenskaps- en opcrasiesaalverpleging beskik. Albei beskik oor die kwalifikasie Verpleegadministrasie, een is gekwalifiseerd in Verpleegonderwys en een in Intensiewe Verpleegkunde.

Bergman (1982: 8) stel vermoëns (kennis, vaardighede en waardes) as 'n voorwaarde vir aanspreeklikheid. 'n Ontleding van die gegewens cor die professionele kwalifikasies van verplecgadministrateurs in privaathospitale dui daarop dat sy/hy nie toereikend voorberei is vir haar/sy bestuursverantwoordelikhede nie maar oor genoegsame kliniese kennis beskik om die nodige gehal tebeheer en -versekering in die verskeie dissiplines uit te oefen.

\section{c) Hoogste professionele verpleegkundige kwalifikasie}

Die meeste respondente, naamlik een-envyftig (75\%), beskik oor 'n na-basiese diplo$\mathrm{ma}(\mathrm{s})$ as die hoogste professionele kwalifikasie. 'n Baccalaureusgraad is die hoogste professionele verpleegkundige kwalifikasie vir tien (14\%) respondente terwyl 'n honneurs- en magistergraad onderskeidelik deur een $(2 \%)$ respondent elk as hoogste kwalifikasies aangetoon is (vergelyk figuur 2).

$\mathrm{Vyf}(7 \%)$ respondente het slegs Algemene Verpleegkunde, in die vorm van 'n basiese diploma, as hoogste kwalifikasie aangedui waarvan twee in die Kaapprovinsie en drie in Transvaal werksaam was. Daar moet egter in gedagte gehoe word dat nege (13\%) respon- dente in kleiner hospitale werksaam is (vergelyk figuur 4).

'n Verdere ontleding van die gegewens in die kruistabelle toon dat die gegradueerdes hoofsaaklik vanuit 'Transvaal afkomstig is. ' $n$ Baccalaureusgraad, wat deur tien respondente aangedui is, word deur een respondent in beide die Kaapprovinsie en Natal aangedui en die res, naamlik agt respondente, is uit die Transvaal afkomstig. Beide die honneurs- en magistergrade is deur verpleegadministrateurs in Transvaal as hoogste professionele verpleegkundige kwalifikasie aangetoon.

Die twee nasionale verpleegadministrateurs in hierdie studie is albei gegradueerd met een respondent wat ' $n$ baccalaureusgraad en een wat 'n magistergraad as hoogste kwalifikasie aangetoon het.

Robertson (1984: 252) bevind in haar studie dat $10 \%$ en $25 \%$ verpleegadministrateurs in stedelike provinsiale hospitale oor ' $n$ basiese en na-basiese baccalaureusgraad onderskeidelik beskik. Die verpleegadministrateur in privaathospitale is primèr gediplomeerd en slegs $18 \%$ is gegradueerd.

Indien die sestien respondente wat tans met verdere formele studie besig is hul studies suksesvol voltooi, behoort die geprojekteerde getal gegradueerde verpleegadministrateurs in privaathospitale na $38 \%$ te styg.

\section{d) Nie-verpleeglaundige kwalifikasies}

Slegs vyf $(7 \%)$ respondente het aangedui dat hulle oor nieverpleegkundige kwalifikasies beskik. Hierdie kwalifikasies sluit diploma's in hoër onderwys, arbeidsverhoudinge, sekretariële dienste en besigheidsbestuur ("Business Science") in. Een respondent beskik oor 'n B.Sc.-graad (Wiskunde en Statistiek). Hierdie resultate is in ooreenstemming met die tendens in stedelike provinsiale hospitale waar $11,3 \%$ verpleegadministrateurs oor nie-verpleegkundige kwalifikasies beskik (Robertson, 1984: 250).

\section{e) Formele studie}

Bykans een kwart van die respondente, naamlik sestien (23\%), het aangedui dat hulle met voortgesette onderwys in die vorm van verdere formele studie besig was. Twaalf (18\%) respondente is tans besig met B.A.(CUR.) by die universiteit van Suid-Afrika terwyl, die ander vier respondente elk besig is met verdere formele studie in besigheidsbestuur, B.A (Sielkunde), LLB, en MBL. Een nasionale verpleegadministrateur het ook aangedui dat sy met verdere formele studie besig is. Dit blyk dat 'n groot aantal verpleegadministrateurs in privaathospitale gretig is om hulself verder te bekwaam.

\section{f) Redes waarom studies nie voortgesit word nie}

Vir die twee-en-vyftig (77\%) respondente, wat aangedui het dat hulle nie tans besig is met verdere formele studie nie, blyk werkla- ding die vernaamste rede te wees wat deur vier-en-dertig (65\%) respondente aangedui is Sestien $(31 \%)$ respondente het geen behoefte aan verdere studie nie terwyl veertien (27\%) respondente gesinsverantwoordelikhede as 'n belangrike rede aangegee het. Tien (19\%) respondente het aangevoer dat die kursusse op ongeleě tye aangebied word en nege respondente $(17 \%)$ was van mening dat die kursusse te duur is.

Ander redes wat deur nege (17\%) respondente aangegee is, het hoofsaaklik om "te na aan aftree-ouderdom", "geen studieverlofvoordele", "rus 'n bietjie" en "betaal te duur vir kinders se opleiding", gewentel $(\mathrm{N}=52)$.

\section{Indiensnemingsinligting}

In hierdie afdeling is inligting versamel betreffende provinsie van indiensneming, indiensnemingstatus, huidige pos deur respondente beklee, asook die grootte van die hospitaal en aard van verpleging wat gelewer word.

\section{a) Provinsie van indiensneming}

Die meeste respondente, naamlik een-en-veertig $(60 \%)$ was ten tye van die ondersoek werksaam in Transvaal, gevolg deur sewentien (25\%) respondente in die Kaapprovinsie, agt (12\%) respondente in Natal en slegs twee (3\%) respondente in die Oranje-Vrystaat (vergelyk figuur 3 ). 'n Ontleding van die gegewens in tabel 1 toon dat die privaathospitale goed verteenwoordig was, naamlik $87 \%$ van dié in Transvaal, 57\% van die Kaapprovinsie en $100 \%$ uit beide Natal en die Oranje-Vrystaat, wat ' $n$ betroubare weergawe van die profiel van verpleegadministrateurs in SuidAfrikaanse privaathospitale behoort te reflekteer.

\section{b) Indiensnemingstatus}

Slegs een (2\%) respondent het aangedui dat sy in 'n deeltydse hoedanigheid in diens geneem is. Hierdie respondent was vanuit die kleiner hospitaalkategorie, naamlik $1-49$ beddens, in Transvaal afkomstig.

\section{c) Huidige Pos}

Twee (3\%) respondente beklee die pos van nasionale verpleegadministrateur teenoor ses-ensestig $(97 \%)$ respondente wat die verpleegadministrateur (matrone) in beheer van die diens is. Die nasionale verpleegadministrateurs was ten tye van die ondersoek in Transvaal en die Kapprovinsie onderskeidelik gestasioneer.

\section{d) Grootte van kliniek/hospitaal}

Die meeste respondente, naamlik drie-en-twintig $(34 \%)$ het die hospitaal grootte van 100 199 beddens verteenwoordig terwyl een-en-twintig ( $31 \%$ ) respondente die hospitalgrootte 200 en meer beddens verteenwoordig het. Die kleiner hospitale, naamlik 50-99 en $1-49$ beddens, is onderskeidelik deur dertien $(19 \%)$ en nege (13\%) respondente verteenwoordig (vergelyk figuur 4 ). Die twee 
nasionale verpleegadministrateurs is nie in aanmerking geneem nie.

'n Analise van die gegewens in tabel 1 toon dat daar tans slegs twintig en negentien hospitale in die hospitaal grootte 100-199 en 200 en meer beddens onderskeidelik in Suid-Afrika is. Die afleiding kan dus gemaak word dat daar intussen uitbreidings plaasgevind het wat die getal hospitaalbeddens in enkele hospitale laat toeneem het.

\section{e) Aard van verpleging}

Die aard van verpleging in die privaathospitale, waarvoor die verpleegadministrateurs aanspreeklik is, bestaan hoofsaaklik uit die mediese, chirurgiese en operasiesaaldissiplines en verskeie ander spesialiteitsvelde. Die mediese dissipline is deur drie-en-sestig (92\%) respondente aangedui, die chirurgiese dissipline deur ses-en-sestig (97\%) respondente en operasiesaalverpleging deur vier-ensestig $(94 \%)$ respondente.

Intensiewe sorg word deur die hospitale van agt-en-veertig ( $71 \%$ ) respondente verskaf terwyl ortopedies ook 'n groot deel van die verpleegpraktyk uitmaak. Dit word naamlik deur vyf-en-vyftig ( $80 \%$ ) respondente se hospitale gelewer.

Verloskundige dienste word deur een-en-dertig (46\%) respondente se hospitale gelewer en pediatriese verpleegdienste is deur sewe-enveertig (69\%) respondente aangedui. Dit is interessant om daarop te let dat onkologiese dienste deur twintig (29\%) respondente se hospitale verskaf word.

"Ander" dienste is deur agt (12\%) respondente aangedui, wat hoofsaaklik psigiatrie, ongevalle, en 'n verduideliking van verskeie chirurgiese en mediese spesialiteitsrigtings ingesluit het. Twee respondente het aangedui dat hulle 'n primêre gesondheidsdiens " ... at the estate clinics" in Natal aanbied (vergelyk figuur 5). Die verpleegadministrateur in privaathospitale is dus aanspreeklik vir 'n wye verskeidenheid verpleging in die onderskeie hospitale.

\section{Professionele inligting}

Professionele inligting betreffende die respondente se ervaring, duurte van huidige pos, redes vir aanvaarding van ' $n$ bestuurspos in die privaatsektor, asook hul werksbevredi ging en opvoedkundige behoeftes is ingewin en ontleed.

\section{a) Jare van kliniese ervaring}

Slegs twee $(3 \%)$ en vyf $(7 \%)$ respondente onderskeidelik het minder as een jaar en een tol twee jaar kliniese ervaring aangedui. In eersgenoemde groep is een respondent vanuit die Kaapprovinsie en een vanuit Transvaal afkomstig. In laasgenoemde groep is twee respondente vanuit die Kaapprovinsie, een uit die Oranje-Vrystaat en twee vanuit Transvaal afkomstig.
Die meeste verpleegadministrateurs, naamlik vier-en-vyftig (79\%) het vyf of meer jaar $\mathrm{kJ}$ niese ervaring gehad voordat hulle in 'n bestuurspos aangestel is. In hierdie groep is tien respondente werksaam in die Kaapprovinsie, sewe in Natal, een in die Oranje-Vrystat en ses-en-dertig in Transvaal. Dit is interessant om daarop te let dat hierdie data $59 \%$ van die Kaapprovinsie, $88 \%$ van Natal, $50 \%$ van die Oranje-Vrystaat en $88 \%$ van die Transvaalse verpleegadministrateurs weerspiexl. Sewe (10\%) respondente het drie tot vier jaar kliniese ervaring gehad waarvan vier in die Kaapprovinsie, een in Natal en twee in Transvaal werksaam was

Hierdie resultate vergelyk gunstig met Robertson (1984: 253) se bevindinge waar $71,7 \%$ verpleegadministrateurs in stedelike provinsiale hospitale vyf jaar of meer kliniese ervaring as 'n saalsuster gehad het.

'n Analise van hierdie gegewens toon dat die verpleegadministrateur in privaathospitale klinies ervare verpleegpraktisyns is, wat die tradisionele loopbaanontwikkelingspatroon gevolg het voordat hulle in ' $n$ bestuurspos aangestel is.

\section{b) Areas van kliniese ervaring}

Die verpleegareas waarin die verpleegadministrateurs van privaathospitale ten minste ses maande kliniese ervaring as 'n geregistreerde verpleegkundige opgedoen het voordat hulle in ' $n$ bestuurspos aangestel is, vol $g$ ' $n$ voorspelde patroon.

Die meeste respondente, naamlik sestig ( $88 \%$ ) het hierdie ervaring in beide mediese en chirurgiese verpleegdissiplines aangedui. Daarna volg ervaring in die verloskundige verpleegpraktyk deur agt-en-veertig (71\%) respondente en vier-en-dertig (50\%) respondente wat ervaring in operasiesaalverpleging het.

Ortopediese verpleegervaring is deur vier-endertig (47\%) respondente aangedui waarna pediatrie met sewe-en-twintig (40\%) respondente en intensiewe verpleging met sestien (23\%) respondente volg. Gemeenskaps- en psigiatriese verpleging blyk die dissiplines te wees waarin minder kliniese ervaring voorkom, naamlik twaalf ( $18 \%$ ) en elf (16\%) respondente onderskeidelik. Daar was slegs vier $(6 \%)$ respondente wat aangedui het dat hulle oor onkologiese verpleegervaring beskik. Dit wil voorkom asof hierdie 'n verpleegpraktyk is wat tans in die privaatsektor uitbrei aangesien $29 \%$ respondente aangedui het dat hierdie tipe verpleging in hul hospitale beoefen word.

Ervaring as dosent in verpleging is deur agtien (26\%) respondente aangedui. "Ander" tipes ervaring is deur agt (12\%) respondente aangetoon en sluit hoofsaaklik infeksiebeheer, ongevalle, stomaterapie en "staff heal th care" in. 'n Hoe persentasie (50\%) respondente het ervaring in operasiesaalverpleging.
Dit wil dus voorkom asof die verpleeg administrateurs in privaathospitale oor die algemeen oor die nodi ge kliniese agtergrondkennis beskik, met die uitsondering van psigiatriese, gemeenskaps- en onkologiese verpleging, om die nodige gehalteversekering te kan toepas.

\section{c) Duur van huidige pas}

Die huidige bestuurspos word deur agt (12\%) respondente vir minder as twee jaar bekJee terwyl die meeste, naamlik vyf-en-twintig (37\%) respondente die pos reeds vir 'n tydperk van twee tot drie jaar beklee. Die pos word vir drie tot vyf jaar deur elf (16\%) respondente beklee terwyl twaalf (18\%) respondente die pos vir vyf tot tien jaar en meer onderskeidelik beklee. Dit wil dus voorkom asof ongeveer $50 \%$ van die verpleegadministrateurs in privaathospitale hul huidige pos vir langer as drie jaar bekJee, wat relatiewe stabiliteit aandui.

Robertson (1984: 256) bevind in haar studie dat $49 \%$ verpleegadministrateurs in stedelike provinsiale hospitale hul poste vir minder as vyf jaar beklee het. 'n Totaal van bykans $65 \%$ verpleegadministrateurs in privaathospitale beklee hul bestuursposte vir minder as vyf jaar. Die totale bestuurservaring is moeilik berekenbaar aangesien geen inligting oor vorige bestuurservaring, in die openbare sektor of elders, ingesamel is nie.

Selfs die kategorie vyf tot tien jaar (18\%) vertoon swakker as Robertson (1984: 256) se bevinding dat $26 \%$ verpleegadministrateurs hul poste vir hierdie tydperk beklee het. Die resultate in die kategorie elf jaar en meer (18\%) vergelyk egter gunstig met dié van die provinsiale administrateurs, naamlik 18,9\%. Ses uit die een-en-veertig (17\%) verpleegadministrateurs in Transvaalse privaathospitale drie uit die agt (38\%) in Natal en drie uit die sewentien (17\%) in die Kaapprovinsie beklee hul huidige bestuursposte reeds elf jaar of meer.

\section{d) Redes: bestuurspos in privaatsektor aan-} vaar

Belangstelling in bestuur was deur sewe-envyftig ( $84 \%$ ) respondente as die vemaamste rede aangevoer. Beter salarispotensiaal, meer outonomie en "ander redes" is deur agt-entwintig (41\%) respondente as 'n belangrike rede aangegee. Die "ander" redes sluit hoofsaaklik die bevordering vanaf senior verpleegkundige na verpleegadministrateur in.

Frustrasie in vorige werk is deur twintig (30\%) respondente aangedui terwyl hour aansien en meer tyd om aan gesin te bestee deur slegs sewe (10\%) en ses (9\%) respondente onderskeidelik as ' $n$ rede aangegee is

Verskeie respondente het aangedui dat die verpleegadministrateur in privaathospitale meer direk deur die bestuur van die hospitaal by besluitneming betrek word. Die omvang van ver antwoordelikhede en bestuur, afhangende van 
die grootte van dic hospitalc, is ook klciner, wat meer ruimte vir inisiatief aan die verplecgadministrateur laat.

'n Vergelyking met Robertson (1984: 257) se bevindinge toon interessante verskille. Belang stelling in bestuur word deur slegs $39,3 \%$ verpleegadministrateurs in stedelike provinsiale hospitale aangedui teenoor die $84 \%$ in privaathospitale. Gericfliker ure (kantoorure) is deur $19 \%$ van die verpleegadministrateurs in privaathospitale aangedui teenoor slegs $5,6 \%$ in stedelike provinsiale hospitale. Beter salaris of salarispotensiaal is deur $41 \%$ in die privaatsektor, teenoor slegs $9,4 \%$ in die openbare sektor as redes aangevoer. Hicrdie verskil is ook opmerklik in die ervaar van meer outonomie wat deur $41 \%$ in die privaatsektor teenoor $11,3 \%$ in die openbare sektor as ' $n$ rede aangedui is

Bevordering blyk ook in die privaathospitale 'n belangrike rol te speel aangesien ses-entwintig (38\%) respondente dit as 'n rede gespesifiscer het teenoor $22,7 \%$ in die openbarc sektor, soos deur Robertson (1984: 257) bevind.

\section{e) Werksbevrediging}

Minimale werksbevrediging in die huidige pos word deur slegs twee (3\%) respondente (uit Transvaal), ten tye van die studic ervaar, terwyl ses-en-twintig (38\%) respondente gemiddeide/redelike werksbevrediging ervaar het. In die laasgenoemde grocp val negentien in Transvaal.

Die oorgrote meerderheid, naamlik veertig $(59 \%)$ respondente het aangedui dat hulle 'n ho' graad van werksbevrediging ervaar. Twaalf uit die Kaapprovinsie, ses uit Natal, twee uit die Oranje-Vrystaat en twintig uit Transvaal val in hierdie kategorie.

'n Analise van hierdie gegewens toon dat $71 \%(\mathrm{~N}=17)$ van dic verpleegadministrateurs uit die Kaapprovinsie, $75 \%(\mathrm{~N}=8)$ vanuit

Natal, $100 \%(\mathrm{~N}=2)$ uit die Oranje-Vrystaat en slegs $49 \%(N=41)$ uit Transvaal, ' $n$ hoè graad van werksbevrediging in hul huidige bestuursposte ervaar. Hierdie resultate kan moontlik verklaar word vanweè die feit dat slegs $56 \%$ van die verpleegadministrateurs in Transvaalse privaathospitale toercikend vir hul huidige bestuursposte voobcrei vocl, wat moontlik frustasie tot gevolg kan hê.

\section{f) Voorbereidheid vir huidige pos}

Die resultate toon 'n variasic van gevoel onder die respondente. Vyf-en-vecrtig $(66 \%)$ respondente voel dat hulle toereikend voorberei is om aan die cise van hul huidige pos/rol as 'n verplecgadministratcur in 'n privaathospitaal te voldoen. Daar is egler sewentien (25\%) respondente wat vocl dat hulle nie toereikend voorberei is nic en ses: (9\%) het 'n mate van onsckerheid aangedui.

'n Analise van die kruistabelgegewens toxm dat dertien (77\%) respondente in dic Kuappro- vinsic, sewe ( $88 \%)$ in Natal, twee $(100 \%)$ in die Oranje-Vrystaat en drie-en-twintig (56\%) in Transvaal rocrcikend vir hul huidige pos voorbcrei voel. $\mathrm{N}$ die respondente wat onseker gevoel het, te wete ses $(9 \%)$, is uit Transvaal afkomstig.

Robertson (1984: 264) se studie het getoon dat $1,9 \%$ verpleegadministrateurs gevoel het dat hulle uitstekend voorberei was terwyl 73,6\% gevoel het dat hulle tocreikend voorberei was wat ' $n$ total van $75,5 \%$ positiewe antwoorde was. 'n Totaal van $24,5 \%$ het gevol dat hulle ontocreikend of swak voorberei was. Die negatiewe antwoorde stem dus coreen met die bevindinge van hicrdie studic $(25 \%)$. Die verpleegadministrateurs in privaathospitale toon egter 'n matc van onsckerheid, te wete $9 \%$. Hierdie resultate kan moontlik toegeskryf word aan die relatiewe isolasie wat dic verpleegadministrateurs in die privaatsektor ervaar, weens 'n gebrek aan portuurgroepevaluering.

\section{g) Opioedkundige behoefies}

Figure 6 tot 8 bied die resultate van hierdie item aan, gerangskik vanaf die hoogste na dic laagste frekwensie, uitgedruk in persentasies. Die resultate is in drie groepe geklassifiseer, tc wete die oplcidingsbehoeftes wat deur mee as $70 \%$, vanaf $50-69 \%$ en onder $50 \%$ aangedui is.

Die prioriteit persoonlike opvoedkundige behoeftes wat deur die respondente aangedui is, blyk die bepaling van verpleegkundige werkladingindeks, dic samestelling van 'n gebcurlik-heidsplan vir personeclkrisisse, die ontwerp van gehalteversckeringsprogramme en dic ontwerp van evalucringsinstrumente te wees, wat elk deur vyf-en-sestig (96\%) respondente aangedui is.

Die evaluering van gehalteverpleging blyk ook 'n grool personeclontwikkelingsbehoefte vir drie-en-scstig (93\%) respondente te wees, gevolg deur die ontwikkeling van leierskapvaardighede wat vir twee-en-vyftig $(\mathbf{7 7 \%})$ respondente 'n behoefic is.

Konflikbestuur is deur vyftig ( $74 \%$ ) respondente as 'n behocfte aangedui en wetenskaplike verpleging, met betrekking tot die metodes en dokumentering, is vir nege-envecrtig $(72 \%)$ respondente 'n groot behoefte (vergelyk figuur 6).

Dissiplinìre prosedures, asook dic formulering van ' $n$ ver-plecgdiensfilosofie, is beide diur scwc-cn-vecrtig (69\%) respondente as behox:ftes aungedui. I3egroting en finansicle bestuursvaardighede is deur ses-en-veertig $(68 \%)$ respondente as 'n behoeftc aangetoon terwyl dric-en-vecrig (63\%) respondente perscheclontwikkcling in die hantering van gricweprosedures benodig.

Dic mecrderheid respondente, lussen 50-57\%, Jui a:an dat hulle tekonkominge in pasientlicewysingsmetodes, dic skryf en opstel van pewumskrywings, kommunikasicprosedures en personeclevaluering ervaar (vergelyk figuur 7)

'n Verdere 40-49\% respondente ervasr leemtes in die opstel van beleidshandlcidings, die ontwerp van personeelontwikkelingsprogramme, die skryf van doelstellings, keuring van personeel, rampbeplanning, die hoe van personeclrekords en -statisticke, asook beplannings- en organiseringsvaardighede.

Die ander personeelbestuursvaardighede, soos werwing, die aansiclling van personeel, beroepsgesondheidsprogramme, toekenning en skedulering van personcel, is deur ten minste $30 \%$ van die respondente as behoeftes aangedui.

"Ander" behoeftes, wat deur sewe (10\%) respondente aangeteken is, sluit hoofsaaklik produktiwiteitstudies, rekenaarinligtingstelsels en personeelmotiveringsmetodes in. Een respondent het aangedui dat sy graag die struktuur en werkwyses van die Suid-Afrikaanse Verpleegstersvereniging sou wou ken en een respondent het "aspects of cross cultural nursing" as 'n behoefte vitgelig. 'n Ander respondent in Transvaal het aangedui dat die hantering van "agency staff" 'n groot probleem is (vergelyk figuur 8 ).

Wanncer die resultate wat oor professionele kwalifikasies handel, asook dié wat cor hul gevoel betreffende toereikendheid van voorberciding vir dic pos, ontleed word, is dit interessant om op die variasic van hierdie responsc te let. Slegs $66 \%$ respondente het aangedui dat hulle tocreikend vir hul poste voorberei is en slegs $29 \%$ respondente het 'n kwalifikasie in Verplecgadministrasic (vergelyk (iguur 1). Gesien in die lig van hicrdie resultate is dit verrassend dat so min respondente aangedui het dat hulle opvoedkundige bchoeftes in die al gemene bestuursvaardighede, soos beplanning, organiscring, begroting, en so meer, benodig. Hierdie resultate kan verklaar word uit die aanmerkings van 'n groot hocveel heid respondente dat die nodige opleiding in die gesondheidsdiens (hospitaalgroep) asngebied word.

Hierdie resultate toon 'n tecnstrydigheid mel die resultate wat oor die respondente se gevoel van voorbereidheid handel, naamlik dat vyf-en-veertig (66\%) respondente van mening is dat hulle toereikend vir hul huidige bestuursposte voorberei is. Hierdic resultate bevestig egter die verpleegadministrateur in privaathos. pitale sc tckorkominge betreffende ' $n$ formele kwalifikasie in Verplecgadministrasic, waaroor slegs $29 \%$ beskik (vergelyk figuur 1), asook dic relaticf groot getal onervare bestuurders.

\section{GEVOLGTREKKINGS}

Die gevolgtrekkings wat na aanlciding van dic data-ontleding gemaak kan word, is soos volg: 
- Die verpleegadministrateur in Suid-Afrikaanse privaathospitale is 'n vroulike, blanke, persoon met 'n gemiddelde ouderdom van twee-en-veertig jaar.

- Benewens haar bestuursrol vervul die verpleegadministrateur ook 'n gesinsrol wat die versorging van cen of meer afhanklikes insluit.

* Bykans 'n gelyke hoeveelheid Engels- en Afrikaans- sprekendes beklee 'n verpleegadministrateurspos in privaathospitale.

* Die verpleegadministrateur is nie toereikend voorberei vir haar bestuursverantwoordelikhede nie maar beskik oor genoegsame kliniese kennis (volgens die geregistreerde kliniese kwalifikasies) om die nodige gehal tebeheer en -versekering in die verskeie verpleegdissiplines uit te oefen.

- Sy is 'n gediplomeerde persoon. Die geprojekteerde getal gegradueerde verpleegadministrateurs in privaathospitale behoort in die afsienbare toekoms vanaf $18 \%$ na $38 \%$ te styg.

- Die verpleegadministrateurs in privaathospitale is klinies ervare praktisyns wat die tradisionele loopbaanontwikkelingspatroon gevolg het voordat hulle in 'n bestuurspos aangestel is.

- Sy ervaar 'n hoë graad van werksbevrediging. Die verpleegadministrateur wat in Transvaalse privaathospitale werksaam is, ervaar egter minder werksbevrediging.

- Die verpl eegadministrateurs in privaathos pitale se prioriteit opvoedkundige behoeftes, om hulself meer toereikend vir hul huidige bestuursverantwoordelikhede te bekwaam, is hoofsaaklik gesetel in gehalteversekeringsaktiwiteite, die ontwikkeling van leierskapvaardighede en arbeidsverhoudinge.

- Sy ervaar, in ' $n$ mindere of meerdere mate, 'n behoefte aan die ontwikkeling van die meeste bestuursvaardighede ten einde 'n hoß gehalte verpleegdiensbestuur te kan verseker.

\section{AANBEVELINGS}

Die volgende aanbevelings, wat uit die studie voortvloei, word gemaak:

- Die instelling van 'n studieverlofstelsel vir verpleegadministrateurs in privaathospitale sodat hulle die geleentheid kan kry om 'n bestuurskwalifikasie te bekom.

- Die ontwerp en implementering van 'n kortkursus oor bestuursvaardighede, vir lysting by die Suid-Afrikaanse Raad op Verpleging, vir die verpleegadministrateurs in privaathospitale.
- Die samestelling van 'n profiel van die verpleegadministrateurs in alle privaathospitale, insluitende die mynindustrie en gesubsidieerde privaathospitale, vir vergelykende doeleindes.

- 'n Studie oor werksbevrediging, soos deur die verpleegadministrateurs in privaathospitale ervaar

\section{BEPERKINGE VAN DIE STUDIE}

Gestruktureerde posvraelysvoltooiing is afhanklik van die respondent se gewilligheid om eerlike antwoorde te verskaf. Resultate betreffende die profiel van die verpleegadministrateurs in privaathospitale kon moontlik hierdeur beinvloed geword het.

Slegs privaathospitale met ' $n$ winsmotief is by hierdie studie betrek. Statistiese verrekening van verskille cussen provinsiale groepe is bemoeilik op grond van die Oranje-Vrystaat en Natal se lae frekwensiewaardes.

\section{SLOTOPMERKINGS}

Die klemverskuiwing in die Suid-Afrikaanse verpleegadministrateur se roluitlewing vereis bestuursparaatheid deur hierdie praktisyns. Hoèr eise word daagliks aan hierdie bestuurders gestel wat professionele paraatheid noodsaaklik maak. Die verpleegadministrateur in privaathospitale moet dus noodwendig haar/sy bestuursvaardighede verbeter. Die resultate in hierdie studie is ' $n$ aanduiding van die vlak van hierdie paraatheid, soos deur die professionele profiel van die respondente uitgebeeld.

\section{BIBLIOGRAFIE}

BERGMAN, $R$ 1982: The role of the unit sister - emphasis on quality of care and aocountability. Curationis, 5(4), December 1982: 4-9.

BRINK, HIL 1984: The registered nurse tutor in the Republic of South Africa. Pretoria: University of South Africa (D.Litt et Phil. thesis).

CILLIERS, G 1986: Die rol van die verpleegadministrateur in personeelbestuur in hospitale. Pretoria: Raad vir Geesteswetenskaplike Navorsing (verslag nr. MM-113).

GOODRICH, NM 1982: A profile of the competent nursing administrator. Ann Arbor: UMI Research Press.

HOSPITAL \& NURSING YEARBOOK OF SOUTHERN AFRICA 1988. Johannesburg: Thomson Publications.

HUMAN, SP 1987: Die epidemioloogverpleegkundige in HF Verwoerd-hospitaal. Pretoria: Universiteit van Pretoria (M.Cur. verhandeling).
KOMMISSIE VIR ADMINISTRASIE 1986 Personeeladministrasiestandaard: beroepskJas verpleegpersoneel, Bylaag, C. 1986: 13-14.

ROBERTSON, B 1984: The nurse administrator in South Africa. Past and present perspectives, future predictions. Pretoria: University of South Africa (D.Litt. et Phil. thesis)

SNYCKERS, H 1986: Privatisation and deregulation of health care in South Africa. Consolidated report of the four working groups on privatisation and deregulation to the heal th services advisory council (unpublished).

SUID-AFRIKA (Republiek) 1987: Witskrif oor Privatisering en Deregulering in die Republiek van Suid-Afrika. Pretoria: Staats drukker.

SUID-AFRIKA (Republiek) 1988: Wetsontwerp om voorsiening te maak vir die instelling van 'n Raad vir Privaathospitale en vir aangeleenthede wat daarmee in verband staan. Staats-koerant, No. 11396, Julie 1988: 12-16.

SUID-AFRIKAANSE RAAD OP VERPLEGING 1988: Statistiese opgawe vir die kal enderjaar 1988. Pretoria: Suid-Afrikaanse Raad op Verpleging.

SUID-AFRIKAANSE VERPLEEGSTERSVERENIGING 1985: Verpleegkal eidoskoop sensusvraelys. Pretoria: Suid-Afrikaanse Verpleegstersvereniging.

SUID-AFRIKAANSE VERPLEEGSTERSVERENIGING 1989. Verpleegkaleidoskoop: RSA 1984-1987. Pretoria: Suid-Afrikaanse verpleegstersvereniging.

\section{Erkennings}

Erkenning word hiermee verleen aan die SuidAfrikaanse Verpleegstersvereniging en Raad vir Geesteswetenskaplike Navorsing vir finansiële steun. Dankbetuigings aan die verpleegadministrateurs van privaathospitale vir hul merkwaardige respons en deelname aan hierdie studie.

Hierdie artikel is gebaseer op navorsing (gedeeltelik) wat vir die graad D.CUR. aan die Randse Afrikaanse Universiteit gedurende 1989 onderneem is.

\begin{tabular}{|c|}
\hline Marie E Muller \\
Medeprofessor \\
D.CUR. (RAU) \\
Randse Afrikaanse Universiteit \\
MC van Huyssteen \\
Spesiale Professor \\
Departement Verpleegtunde RAU \\
D.CUR (Universiteil Pretoria) \\
Anne-Marie Bruwer \\
Adjunk Direkteur Verpleegdienste \\
Tygerberg Hospitaal \\
D.CUR. (Universiteit Pon Elizabeth) \\
\hline
\end{tabular}


Figuur 1.

Verspreiding van respondente se professionele kwalinkasies ( $N=68$ )

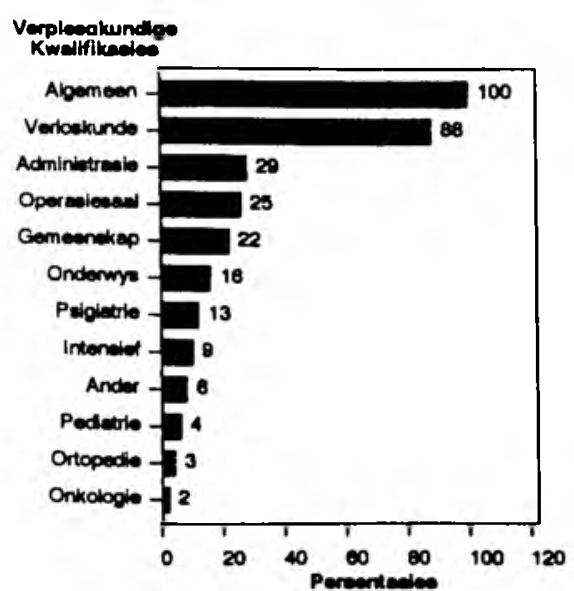

Figuur 4.

Verspreiding van hospitaalgrootte deur respondente verteenwoordig (N=68)

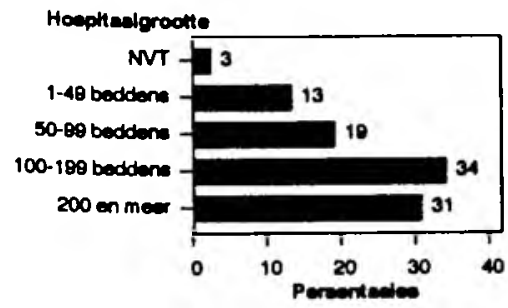

Figuur 7.

Verspreiding van opvoedkundige behoeftes deur $50-69 \%$ respondente aangedui $(\mathrm{N}=68)$

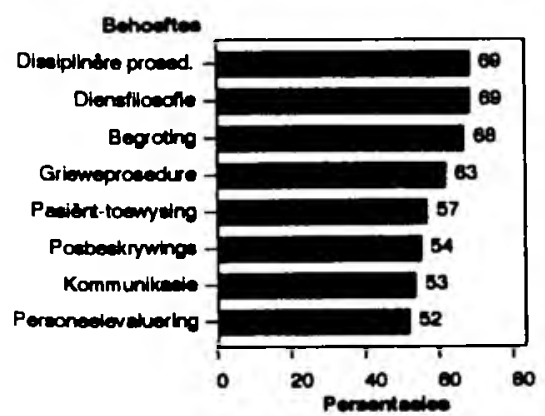

Figuur 2.

Verspreiding van respondente se hoogste professionele verpleegkundige kwalifikasies ( $N=68)$

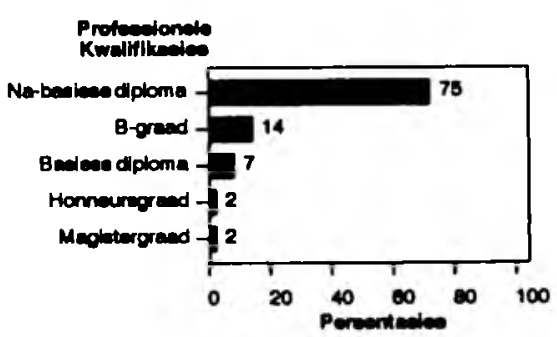

Figuur 3.

Versprelding van respondente volgens provinsie van indlensneming $(N=68)$

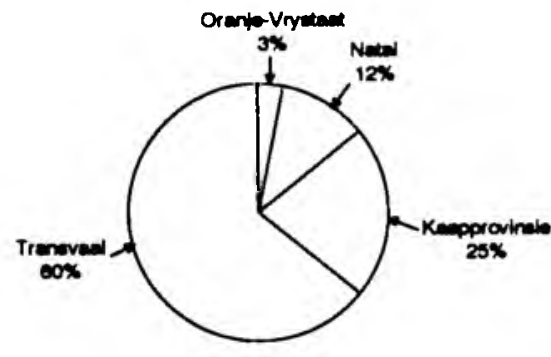

Figuur 5.

Verspreiding van verpleegdissiplines in die hospitaal ( $N=68$ )

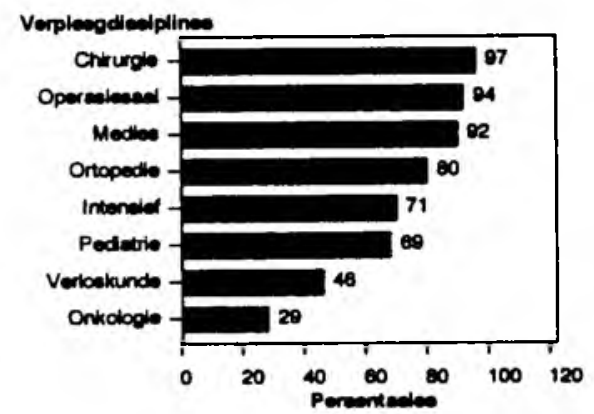

Figuur 6.

Verspreiding van opvoedkundige behoeftes deur meer as $70 \%$ respondente aangedui $(\mathrm{N}=68)$

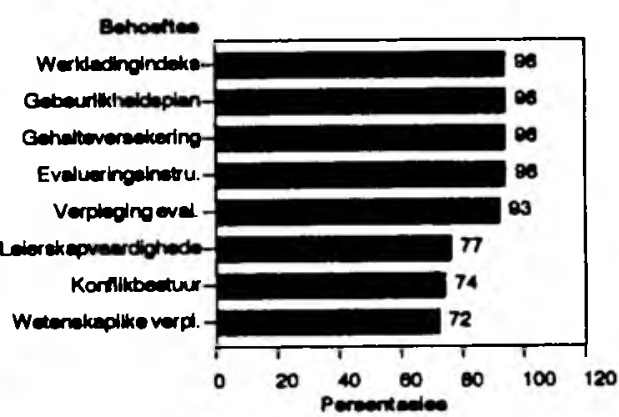

Flguur 8.

Verspreiding van opvoedkundige behoeftes deur minder as $50 \%$ respon-dente aangedui $(\mathrm{N}=68)$

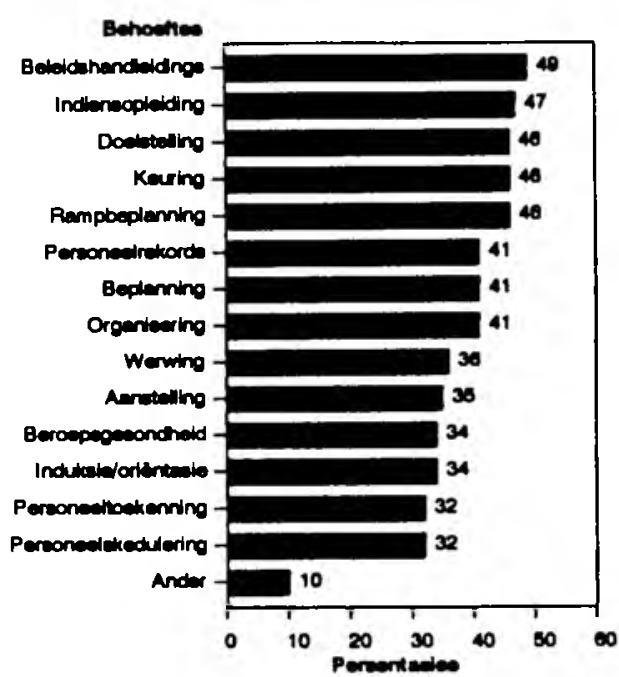

